\title{
sciendo THE INFLUENCE OF EXTERNAL FACTORS ON HAZARDS IN THE TRANSPORT PROCESSES OF SOYBEAN MEAL
}

DOI 10.2478/ntpe-2018-0037

\author{
dr inż. Beata Drzewieniecka \\ dr inż. Jan Drzewieniecki \\ Maritime University of Szczecin, Poland \\ Ing. Miroslav Blatnický, PhD. \\ University of Zilina, Slovak Republic
}

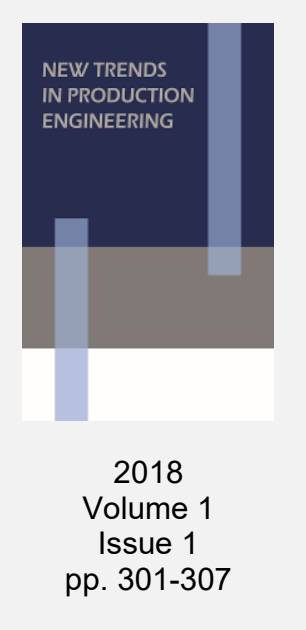

\begin{abstract}
The influence of external factors on changes in the soybean meal quality features has an important meaning in the emergence of hazards during the transport processes of this cargo. Soybean meal is one of the most frequently used components of fodder mixtures. Due to its inherent properties, it is classified as special cargoes. Maintaining the quality of soybean meal during transport processes depends on storage, handling and transport conditions. The main external factor included in the study was humidity. Transport-technological quality features were distinguished: kinetic angle of repose, size of particles, bulk density, porosity. The article presents the results of research on soybean meal and its separated fractions. There was presented humidity influence on changes in significant features for this cargo. Type and range of changes in the distinguishing features of soybean meal were determined in the given stages of the transport chain under the influence of humidity. The risk was assessed in the transport processes of soybean meal. A correlation was determined between changes of individual features and water content in soybean meal changing as a result of air humidity. It was found that humidity of the ambient air in which transport processes occur and size of grain particles of soybean meal have a significant impact on changes in transport-technological quality features.
\end{abstract}

Keywords: soybean meal, humidity, density, angle of repose, porosity

\section{INTRODUCTION}

Soybean meal is one of the most popular fodder's ingredients in the world. The increasing demand for this product in production of fodders puts ever greater demands on safety during transport processes. Soybean meal in transport processes occurs in the form of solid bulk cargo. It is classified according to IMDG Code as a dangerous good in Class 4.2. The influence of external factors on the change of technological and transport characteristics in soybean meal has a significant impact. One of them is humidity of surrounding air. This factor influences changes of water content in soybean meal and changes in transport-technological quality features as well as hazards in transport processes. In these processes, humidity of ambient air as a result of diurnal and seasonal fluctuations, changes water content in soybean meal. This applies especially to sea transport, in which the changes of these parameters are additionally caused by the change of climate zones (Drzewieniecka, 2016). Water content in soybean meal from the production process is thus changed during transport. Absorbing and water vapor into the environment causes considerable difficulties in the transport of soybean meal, especially as a loose solid cargo. The soybean meal is a hygroscopic cargo. Water content adversely affects the transport characteristics that are important in transport, such as: bulk density, natural (kinetic) angle of repose, porosity, i.e. properties that determine the utilization of cargo space, means of transport, storage area and susceptibility to transverse pouring of cargo onto the ship's sides (athwart on board) during sea passage. In addition, there are other hazards. High water content in soybean meal and presence of fine fractions can lead to self-heating and even self-ignition. During sea transport of soybean meal the factors conducive to these processes include (Drzazgowski, 1984): high humidity in the holds and inadequate regulation, exposure of cargo to moisture and wetting, small storage area in the vessel's hold, limited ability to control the temperature of soybean meal 
and the removal of accumulated heat, large soybean meal fineness and a relatively long transport time.

Soybean meal is included in class 4.2 as self-igniting materials. The remaining after the soybean meal extraction of the solvent vapor in the cargo and the presence of dust fractions can lead to an explosion. Dust explosions are among the common causes of hazards on ships and in silos. The factor initiating this phenomenon is the mixture of dust and air floating in the space above the load and its contact with the heat source in the form of hot surfaces or sparks from the electrical installation (Dyduch, 2007). The force and violence of the dust explosion depends, among other things, on the humidity and explosive temperature of the dust and air mixture (Prusiel and Łapko, 2011, Abbasi, 2017).

During cargo handling operations of bulk soybean meal, there is a rapid movement of particles and the formation of dust. In addition to the larger particles, soybean meal also includes fine and dusty fractions, constituting about $4 \%$ of the total cargo, which pose a danger of explosion (Drzewieniecka, 2010).

The presence of residual solvent in soybean meal after the oil extraction process also creates a risk of explosion. The dust explosion limits depend on the humidity. The dust explosion ability decreases with increasing humidity. Dust explosion limit for dry soybean meal is $20 \div 100 \mathrm{~g} / \mathrm{m}^{3}$, soybean meal with $9 \%$ of moisture content $-300 \div 1000 \mathrm{~g} / \mathrm{m}^{3}$. Dust with a moisture content above $16 \%$ does not explode (Drzazgowski, 1984, Dyduch, 2007). Transported, handled and stored soybean meal is exposed to atmospheric factors. Especially, as a hygroscopic cargo, soybean meal is exposed to humidity of surrounding air. This factor affects the change of water content in soybean meal, which leads to adverse phenomena hindering transport processes. These include the reduction of flow, causing among other things, caking of cargo and forming agglomerated clumped layers, resulting in a suspension of cargo in silo outlet openings and reducing the permeability of transmission pipelines and, consequently hindering cargo handling operations. The soybean meal particles size and time of transport and storage also influence on cargo caking and clumping (Zhang et al., 2013, Ganesan et al., 2008).

The flatter cargo particles are and the greater amount of fine particles is present, and the higher water content is, then the greater tendency to a progressive over time caking and compaction is present. The course values of these disadvantageous processes are increase in bulk density of cargo and reduce in its porosity. Significant porosity of soybean meal facilitates the preservation of treatments such as airing, drying and pest control (Cichoń \& Lisińska-Kuśnierz, 1988). Other negative effects of cargo compaction are easier movement and microbial growth leading to selfheating. Moisten soybean meal, especially in case of restricted air access, is quickly brewed. The temperature of such soybean meal is systematically increasing causing self-heating, referred to as microbial self-heating.

The distinctive transport and technological features, among others: the natural angle of repose, the size of particles, specific mass, bulk density and porosity, are important in the transport processes of bulk cargoes including soybean meal.

Bulk density is a property that characterizes all bulk materials. The value of bulk density is needed when designing the capacity of flat warehouses and silos, and when calculating the efficiency of transport equipment. The value of this distinguishing factor depends on the water content, degree of fragmentation and storage time (Zaalouk \& Zabady, 2009, Drzewieniecka, 2004, Walczyński, 1995).

The specific mass depends on water content of the particles because the particle volume increases with its growth (Leśmian-Kordas \& Drzewieniecka, 2001).

The kinetic angle of repose is the main criterion determining the rules of trimming loose bulk cargo. During transport by sea a lot of solid cargoes carried in bulk tend to pour athwart onto board the ship, causing a shift in the ship's gravity center and then a list favoring further pouring of the cargo, which is likely to lead to loss of stability and the vessel's sinking. The kinetic angle of repose is for this reason a measure of safety for carrying solid cargoes by sea. With respect to this criterion cargoes have been divided in the IMSBC Code into three group: I - kinetic angle of repose is smaller than $30^{\circ}$, II - kinetic angle of repose is contained between $30^{\circ}$ and $35^{\circ}$, III kinetic angle of repose is larger than $35^{\circ}$. This division concerns cargoes of respectively large, 
medium and small susceptibility to pouring onto board the ship. Depending on the value of kinetic angle of repose the proper way of trimming is selected precluding the cargo from shifting.

\section{RESEARCH METHODOLOGY}

The research included natural soybean meal and its extracted fractions in conditions corresponding to those occurring during the course of transport processes and correlations between the changes of individual distinguishing features and the external factor causing these changes.

The test results were statistically developed. The analysis of variance for single classification (ANOVA) was used for statistical analysis of the test results. In the case, when the assumption about homogeneity of variance was not met, there was applied a non-parametric alternative to the analysis of variance of simple classification, the Kruskal-Wallis test. In order to determine the statistical relationship between the analyzed variables, correlation coefficients were calculated.

The grain composition of soybean meal was determined in accordance to PN-89/R-64798 by mechanical passing through the sieve of soybean meal samples. From natural soybean meal $(O)$ were isolated fractions with a particle size larger than $3 \mathrm{~mm}(\mathrm{~A})$ and ranges: $1.2-3 \mathrm{~mm}(B), 0.4-$ $1.2 \mathrm{~mm}(C), 0.25-0.4 \mathrm{~mm}(D), 0.1-0.25 \mathrm{~mm}(E), 0.075-0.1 \mathrm{~mm}(F)$, as well as a fraction with a particle size smaller than $0.075 \mathrm{~mm}(\mathrm{G})$ - dusty fraction. Density - specific mass, determined using the Erdmenger - Mann method (Biały, 2013), (Leśmian-Kordas et al., 2001). The bulk density was determined using the method given in PN-EN 1236:1999, identical to the ISO 3944:1992 standard. The porosity was determined - expressed as percentage ratio of the volume of air in the spaces between the particles of soybean meal to the total volume of the sample. The kinetic angle of repose was determined by the method described in the IMSBC Code - the "tilting box test" method used in laboratories and loading ports in the study of non-cohesive fine-particle goods.

\section{DISCUSSION OF RESULTS}

Experimentally determined values of natural soybean meal specific gravity and individual fractions were smaller at $10 \%$ of water content compared to dry samples (at $0 \%$ of water). The density of natural soybean meal at $10 \%$ of water content was $1.19 \mathrm{~g} / \mathrm{cm}^{3}$, and the dry soybean meal was $1.25 \mathrm{~g} / \mathrm{cm}^{3}$. The values of the specific mass of individual soybean meal fractions were also lower at $10 \%$ of water content and were on average $1.23 \mathrm{~g} / \mathrm{cm}^{3}$, and the fraction of dry soybean meal $1.27 \mathrm{~g} / \mathrm{cm}^{3}$.

The value of natural soybean meal bulk density was higher at $10 \%$ of water content and amounted to $0.593 \mathrm{~g} / \mathrm{cm}^{3}$, and for dry soybean meal was $0.584 \mathrm{~g} / \mathrm{cm}^{3}$. The bulk density of individual soybean meal fractions were also higher at $10 \%$ of water content and on average 0.61 $\mathrm{g} / \mathrm{cm}^{3}$, and the dry fraction was $0.58 \mathrm{~g} / \mathrm{cm}^{3}$ (Fig. 1).

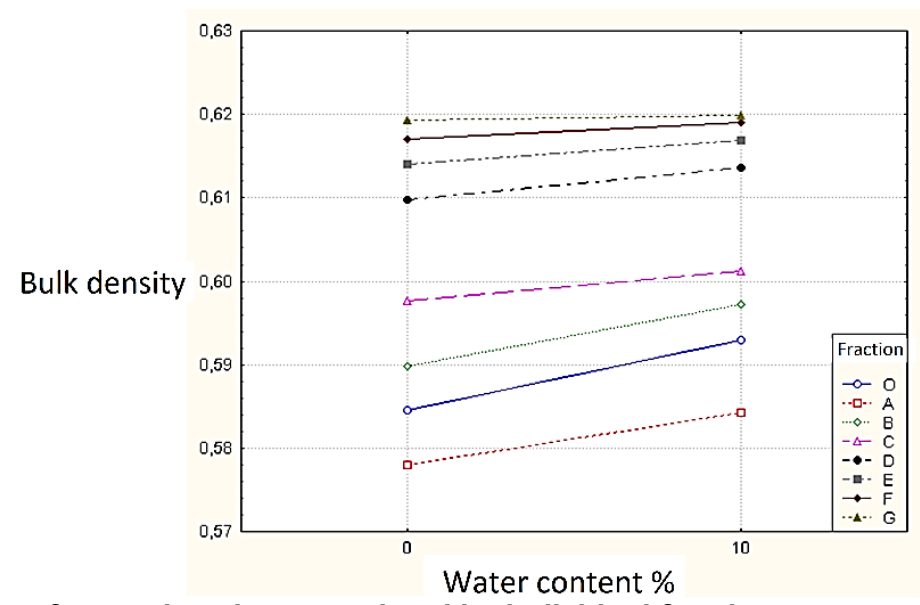

Fig. 1. Bulk density of natural soybean meal and its individual fractions at water content 0 and $10 \%$. 
A significant relationship was found between the bulk density and water content in soybean meal. At the significance level $\alpha=0.05$, the bulk density value at water content 0 and $10 \%$ in soybean meal varied statistically, and the correlation coefficient was 0.61 .

The studies have shown a significant relationship between the bulk density of soybean meal and the size of particles (Fig. 2). At the level of $\alpha=0.05$, the bulk density values of individual fractions were statistically different. The correlation coefficient was 0.83 . As the particle size decreased, bulk density values increased.

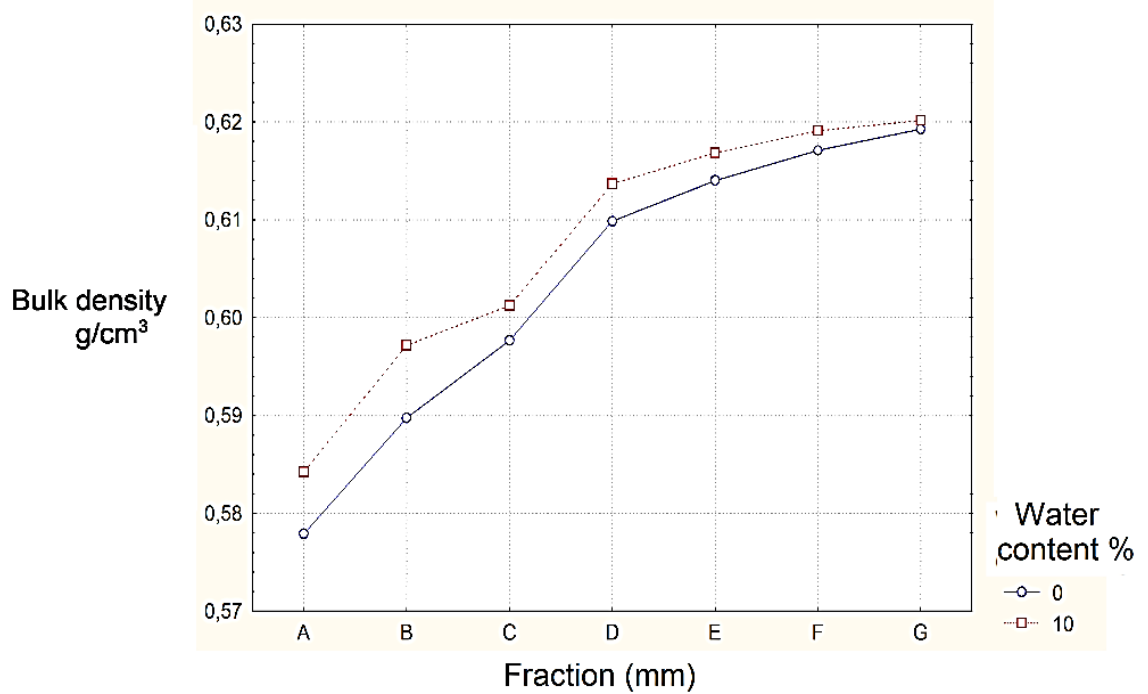

Fig. 2. Comparison of bulk density of soybean meal fractions at water content 0 and $10 \%$.

A similar relationship was demonstrated at the specific gravity. The smaller particles of soybean meal, the more the value of the specific mass increased.

The research has shown a significant relationship between porosity and water content in soybean meal. The correlation coefficient was 0.87 . The porosity in natural soybean meal was higher at $0 \%$ of water content than at $10 \%$ and was respectively 53.36 and $50.30 \%$. Porosity of various soybean meal fractions was higher for dry soybean meal and was $52.76 \%$, and for soybean meal of water content $10 \%-50.40 \%$ (Fig. 3).

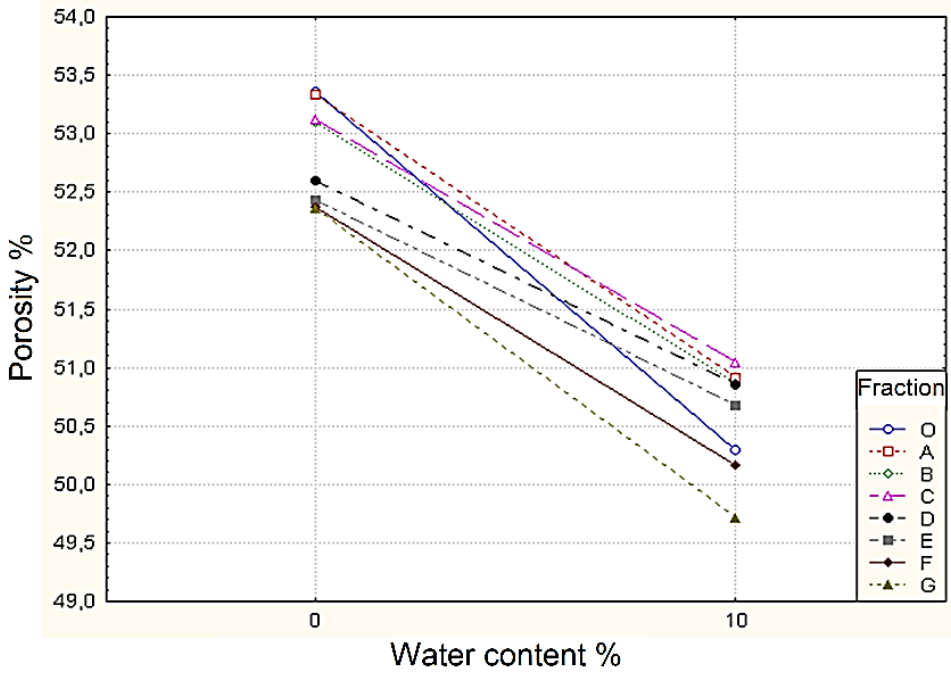

Fig. 3. Porosity of natural soybean meal and its fractions at water content 0 and $10 \%$.

A significant relationship was found between porosity and particle size of soybean meal. At $0 \%$ of water content, porosity decreased significantly with the decrease of soybean meal size, and the 
correlation coefficient was 0.79 . Similarly, at $10 \%$ of water content, porosity also decreased (Fig. 4). The correlation coefficient was 0.82 .

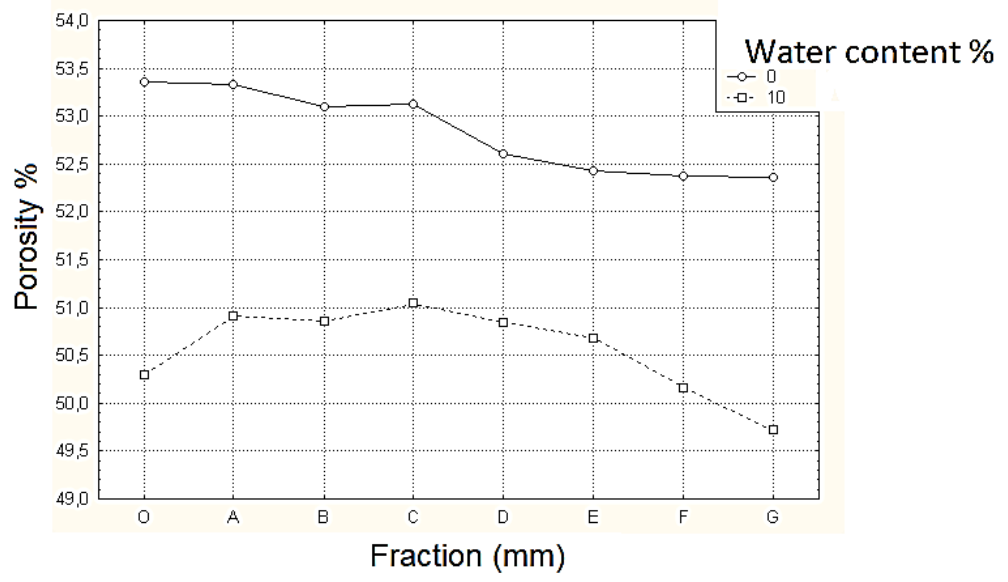

Fig. 4. Dependence of soybean meal porosity on particle size at water content of 0 and $10 \%$

The porosity decreased significantly as the particle size of soybean meal decreased, and the correlation coefficient was 0.79 . Significant dependence was found between the kinetic angle of repose and the water content in soybean meal. At $10 \%$ of water content, the kinetic angle of repose was higher than at $0 \%$ of water content (Fig. 5). The value of kinetic angle of repose for soybean meal at $10 \%$ of water content was $30.1^{\circ}$ and for dry soybean meal $29.5^{\circ}$. The average value of kinetic angle of repose for all fractions was higher by $1.5^{\circ}$ in case of humid soybean meal than in dry one. At the significance level of $\alpha=0.05$, the value of the kinetic angle of repose at humidity 0 and $10 \%$ varied statistically. The correlation coefficient was 0.67 . The kinetic angle of repose decreased with reduction of particle size, for fractions with particles larger than $3 \mathrm{~mm}(\mathrm{~A})$ and in the range of $1.2-3 \mathrm{~mm}(B)$ and $0.4-1.2 \mathrm{~mm}(C)$. From the fraction: $0.25-0.4 \mathrm{~mm}(\mathrm{D})$; $0.1-0.25 \mathrm{~mm}(E) ; 0.075-0.1 \mathrm{~mm}(F)$ and below $0.075 \mathrm{~mm}(\mathrm{G})$, with the decrease of the particle size, the kinetic angle of repose increased (Fig. 5). With the reduction of particle dimensions, the kinetic angle of repose decreased, while in case of fine and dusty fractions $(D, E, F, G)$ the reduction of particle size was accompanied by the increase of this angle.

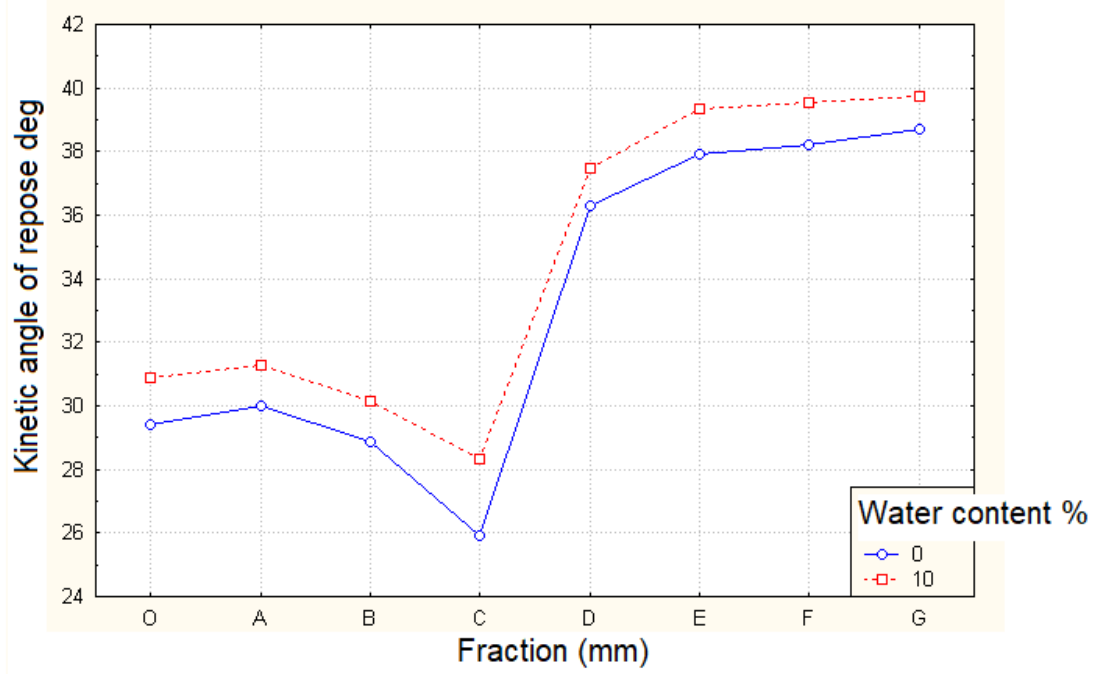

Fig. 5. Dependence of natural (kinetic) angle of repose of natural soybean meal and its individual fractions on the particle size at different water content.

The values of specific gravity, bulk density and porosity obtained in these studies are not much different from those quoted in the literature (Grochowicz, 1996, Drzewieniecka, 2010). It was found that increasing the water content by $10 \%$ did not significantly affect the specific gravity, as the particle size decreased the specific mass increased. Water content and particle size 
influenced the value of bulk density and porosity. The increase in water content caused an increase in bulk density and a reduction in porosity. Analogous relations occurred in particular fractions. As the particle size decreased, the bulk density increased, while the porosity decreased. Taking into account, the set values of kinetic angle of repose and safety of sea transport of bulk soybean meal, it should be stated that the fine and dusty fractions (D, E, F, G) pose a slight risk of athwart pouring of cargo onto the ship's sideboards (angles $>35^{\circ}$ ). The natural soybean meal and fractions $\mathrm{A}$ and $\mathrm{B}$, considering the kinetic angle of repose according to IMSBC Code classification, belong to the cargoes with medium susceptibility to pour athwart on ship's sideboard (angles in the range of $\left.30-35^{\circ}\right)$. The fraction $\mathrm{C}(0.4-1.2 \mathrm{~mm})$ is distinguished in this case unfavorably. The determined kinetic angles of repose for this dry and moist fraction were only $26^{\circ}$ and $28.4^{\circ}$, which means that the susceptibility to pouring on the ship's sideboards is high.

\section{CONCLUSION}

Research on the impact of water content on the distinguishing features of soybean meal made in two variants: dry $(0 \%)$ and moist $(10 \%)$ soybean meal showed that the increase in water content causes: increase of bulk density, increase of kinetic angle of repose and reduction of porosity.

The size of soybean meal particles significantly affected the technological-transport quality factors.

The presence of fine dust fractions has a generally unfavorable impact on the course of transport processes (caking, suspension of meal in silo chambers, dusting during reloading operations, reduction of porosity, explosion).

The positive influence of the presence of fine fractions was marked with respect to kinetic angle of repose in the case of dusty fractions - with particles smaller than $0.4 \mathrm{~mm}$, they were larger than $35^{\circ}$, which protects the cargo against pouring athwart on ship's sideboard.

\section{REFERENCES}

Abbasi T., Abbasi S.A. (2007). Dust Explosions - Cases, causes, consequences and control. Elsevier B.V.

Biały W. (2013). The effect of experimental research on the durability and reliability of mining equipment. Scientific Journals of the Maritime University of Szczecin. 34.

Cichoń M., Lisińska-Kuśnierz M. (1988). Technika i technologia przechowywania artykułów spożywczych. Wyd. AE. Kraków.

Drzazgowski Z., Supernat W., Witalewski T. (1984). Załadunek i bezpieczny przewóz makuchów statkami drobnicowymi PLO. Instytut Morski. Gdańsk.

Drzewieniecka B. (2010). Effect of transport and technological quality factors of soybean seed cake on sea transport safety. Scientific Journals of the Maritime University of Szczecin. 23.

Drzewieniecka B. (2013). Effect of soybean seed cake fractions for safety in maritime transport. Scientific Journals of the Maritime University of Szczecin. 34.

Drzewieniecka B. (2016). Changes in functional quality factors of soybean meal during transport processes. Environmental Aspects of Quality. Radom. pp. 156-163.

Dyduch Z. (2007). Zagrożenie wybuchem pyłu podczas składowania i przetwarzania surowców spożywczych. Ochrona Przeciwpożarowa. 2 (20).

Ganesan V., Rosentrater K.A., Muthukumarappan K. (2008). Flowability and handling characteristics of bulk solids and powders - a review with implications for DDGS. Biosystems Engineering. Vol. 101. pp.425-435.

Grochowicz J. (1996). Technologia produkcji mieszanek paszowych. PWRiL. Warszawa.

Leśmian-Kordas R., Pilawski T. (1990). Towary pochodzenia roślinnego i zwierzęcego w transporcie morskim. ZN WSM. Szczecin.

Leśmian-Kordas R.(1996). Higroskopijność naturalnych paliw stałych. Studia WSM. Szczecin No 26.

Leśmian-Kordas R. (2001). Terminy i definicje wybranych właściwości fizycznych ładunków istotnych w składowaniu, przeładunku i przewozie. ZN WSM. No 61. Szczecin.

Leśmian-Kordas R., Abramowska E., Jóźwiak Z. (2001). Ładunkoznawstwo ogólne. Ćwiczenia. ZN WSM. Szczecin.

Murry A.C., Lewis R.D., Amos H.E. (1997). The effect of microbial phytase in a pearl milletsoybean meal diet on apparent digestibility and retention of nutrients, serum mineral concentration, and bone mineral density of nursery pigs. Journal of Animal Scienc. Vol. 75. pp. 1284-129. 
Łapko A., Prusiel J.A. (2001). Studies on thermal actions and forces in cylindrical storage silo bins. Handbook of Convening and handling of Particulate Solids. Elsevier Science B. V. Amsterdam. The Netherlands.

Prusiel J.A., Łapko A. (2011). Ocena zagrożenia eksplozją pyłów w silosach w świetle norm europejskich. XX Konferencja Naukowo-Techniczna. Awarie budowlane. SzczecinMiędzyzdroje. No 2.

Ulysses A. A. (1997). Handling and storage of soybeans and soybean meal. American Soybean Association. St. Louis. MO.

Walczyński S. (1995). Właściwości fizyczne surowców paszowych. Pasze Przemysłowe. No 1. Lublin.

Zaalouk A.K., Zabady F.I. (2009). Effect of moisture content on angle of repose and friction coefficient of wheat grain. Eng.Dep.Fac .of Ag., Al-Azhar Univ. J. Ag. Eng. 26(1). pp. 418427.

Zhang Y., Yang R., Zhao W., Hua X., Zhang W. (2013). Application of high density steam flashexplosion in protein extraction of soybean meal. Journal of Food Engineering. Vol. 116. pp. 430-435.

Date of submission of the article to the Editor: 05/2018

Date of acceptance of the article by the Editor: 07/2018 